\title{
Evaluation of methods of comparative analysis of sums of atmospheric precipitation measured with the classical method and with a contact-less laser rain gauge
}

\author{
MAŁGORZATA BINIAK-PIERÓG ${ }^{1}$, GABRIELA BIEL ${ }^{2}$, \\ WIESŁAW SZULCZEWSKI ${ }^{2}$, ANDRZEJ ŻYROMSKI ${ }^{1}$ \\ ${ }^{1}$ Institute of Environmental Protection and Development \\ ${ }^{2}$ Department of Mathematics \\ Wroclaw University of Environmental and Life Sciences
}

\begin{abstract}
Evaluation of methods of comparative analysis of sums of atmospheric precipitation measured with the classical method and with a contact-less laser rain gauge. The paper concerns on the evaluation of a preliminary method of comparing data on diurnal sums of atmospheric precipitation acquired with the classic method and by means of Thies Clima laser precipitation monitor - disdrometer. The objective of the study was realized with the use of results of measurements of diurnal sum of precipitation conducted from 1 July to 31 August 2012, in the area of the Faculty Agro and Hydrometeorology Observatory of the Wroclaw University of Environmental and Life Sciences. Information about precipitation measured by means of disdrometer and processed by the authors' software DisPre led to the development of three variants of precipitation totals counting ( 1 - data processed by means of the program supplied as standard by the manufacturer of the disdrometer, 2 - totals calculated from the volume of particular hydrometeors - 11 classes, and 3 - totals calculated basing on droplets' diameters -22 classes). The tests showed that the totals processed by the program supplied by the manufacturer proved to be the closest to the measurements taken with the Hellmann rain gauge as the method of precipitation calculation during a 24-hour period. The reason for the divergences of the observed values should be certainly sought in the method of measurement itself. Due to the high sensitivity of disdrometer on the external factors, it is absolutely necessary to conduct daily checks
\end{abstract}

of cleanliness of the instrument - especially in the summer period.

Key words: precipitation totals, Hellmann rain gauge, laser precipitation monitor, comparative analysis

\section{INTRODUCTION}

Atmospheric precipitation in liquid or solid form constitutes the principal source of water influx to ground surface. Its deficit results in the occurrence of droughts, while an excess often causes floods that can be catastrophic in their effects. For this reason, for over 3 thousand years various attempts have been undertaken, by a large group of experimenters, at designing devices and implementing methods for the measurement of that element (Maciążek 2005, Strangeways 2010). Precipitation sums from various time intervals (an hour, a day, a decade, a month, a half-year) are the necessary input data for analyses in numerous branches of science. That factor is used in studies concerning hydrology, numerical modelling, climate changes, forecasting, remote sensing, or even renewable sources 
of energy (e.g. Wood et al. 2000, Lehner et al. 2005). However, the method of its measurement still remains problematic. This results from the fact that, as opposed to a majority of meteorological factors, it is characterised by a random character, irregularity of spatial occurrence and strong variability over even a small area. Hence the precipitation stations are the most numerous among the measurement points included in the structure of measurement stations of the IMGW-PIB (Instruction 2013).

In accordance with the international standard, as well as WMO-WIGOS and currently in force in Poland, measurement of atmospheric precipitation should be made at the height of $1 \mathrm{~m}$. With relation to the increasingly frequent automation of measurement of that element, and the use of measuring equipment manufactured outside of Poland, there appears a problem resulting from the fact that the manufacturers of such equipment recommend its installation in a manner that is non-compliant with the Polish standard. Indiscriminate adherence to those recommendations may generate measurement errors, and hence the installation of such devices should be adapted every time to the Polish standard (Żyromski and Biniak-Pieróg 2014).

The most classical form of measurement of atmospheric precipitation at altitudes up to $500 \mathrm{~m}$ a.s.l. is the rain gauge originally designed in the $18^{\text {th }}$ century by Georg Gustav Hellmann, that permits the determination of diurnal sums of atmospheric precipitation over the whole year. Another classical mechanical device, but allowing more accurate analysis of precipitations due to the possibility of its continuous recording in time, is the pluviograph. That instrument permits the measurement of both the sum and the intensity of liquid precipitations, and hence its application is limited to the summer half-year only. That rain gauge permits conducting analyses of rainfall intensity for 10-minute intervals, but the stage of data processing is highly labour-consuming.

The interest in atmospheric precipitation resulted in the appearance of various rain gauge designs, permitting much higher levels of accuracy in precipitation measurement. This can be exemplified by the group of weighing precipitation gauges, permitting continuous recording of precipitation influx in time. However, devices of that type are of a limited applicability in winter periods, even when additionally equipped with heaters which, in theory, are to melt down the solid precipitation during winter and thus allow the measurement of its intensity.

Measurements of atmospheric precipitation conducted with the methods described above may be burdened with errors, resulting primarily from wind, wetting, evaporation, rain drop rebounding from the surface, or improper exposition of the instrument (Sieck et al. 2007). Therefore, more modern measurement methods are applied more and more frequently. One of such methods is the optical analysis of precipitation spectrum. An example of such a solution is the contact-less laser precipitation monitor - the disdrometer. That modern gauge permits the measurement of the amount and intensity of precipitations with the identification of the particular types of hydrometeors, i.e. drizzle, rain, hail, snow, or mixed precipitation. It also provides the possibility of acquiring 
information on the structure of precipitation, i.e. droplet size and velocity.

Due to the extensive measurement possibilities of the disdrometer, a study involving its use, one of only a few in Poland, has been conducted in the area of the Faculty Agro and Hydrometeorology Observatory of the Wroclaw University of Environmental and Life Sciences since 2008, at the standard height of $1 \mathrm{~m}$ above ground level. In spite of having the standard software provided by the manufacturer of the instrument, the large amount of data on precipitation acquired at a very short - one-minute-time step inspired the authors to develop new software, DisPre, permitting the analysis of the data acquired adequately to the analyses conducted within the scope of the study (Szulczewski et al. 2013).

Having such a tool at their disposal, the authors decided to develop a preliminary method of comparing data on diurnal sums of atmospheric precipitation acquired with the classic method and by means of the contact-less laser precipitation monitor.

\section{MATERIAL AND METHOD}

The objective of the study was realized with the use of results of measurements of diurnal sum of precipitation conducted from the 1 July to the 31 August 2012, as the intended short-term experiment, in the area of the Faculty Agro and Hydrometeorology Observatory of the Wroclaw University of Environmental and Life Sciences.

Atmospheric precipitation was measured by means of a standard Hellmann rain gauge. In parallel, next to the classical measurement station, measurements of diurnal sums of precipitation were conducted with the use of a ThiesClima contact-less laser rain monitor (Fig. 1a). The instrument operates on the principle of measuring the reduction of light intensity by particles passing through the laser beam. For that purpose a laser diode with an optical system forms a light plane with wavelength of $785 \mathrm{~nm}, 20 \times 228 \mathrm{~mm}$ in dimensions (Fig. 1b).

The photodiode with a lens, situated on the receiver side, continuously measures the intensity of light, converting it

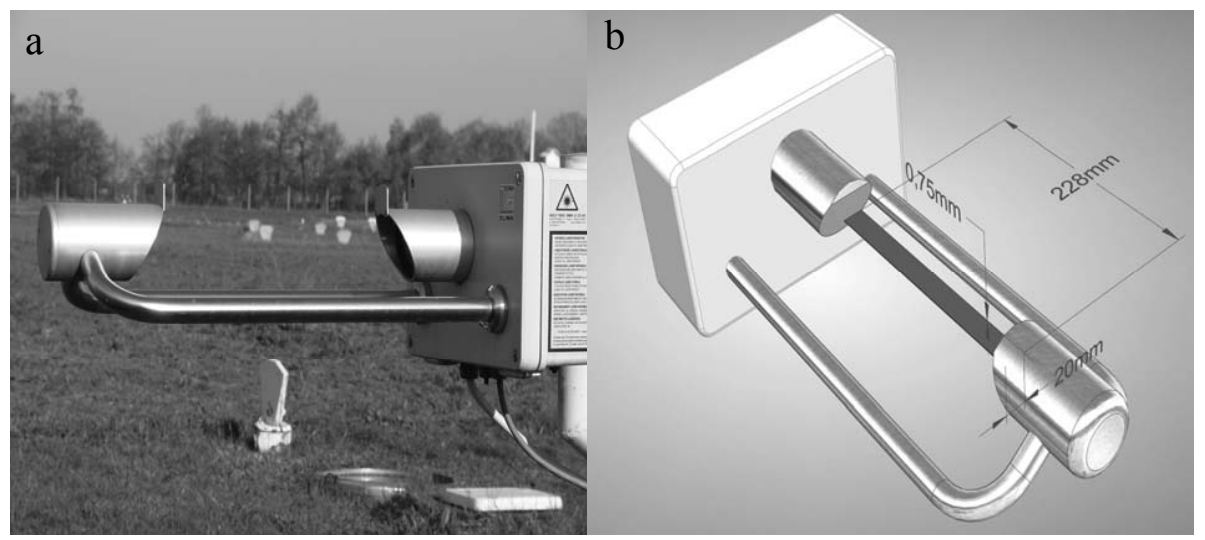

FIGURE 1. ThiesClima laser distrometer installed in the area of the Departmental Agro and Hydrometeorology Observatory, University of Environmental and Life Sciences in Wrocław: a - overall view, $\mathrm{b}$ - operation schematic (own elaboration) 
into an electric signal. When a precipitation particle passes through the light beam, the signal reaching the receiver is reduced. The diameter of the particle is calculated on the basis of the signal attenuation, while its velocity is derived from the duration of that attenuation. To identify liquid or solid precipitation the ambient temperature is measured, and thus e.g. precipitation at a temperature above $9^{\circ} \mathrm{C}$ is classified as liquid, with the exception of hail, while that at a temperature below $-4{ }^{\circ} \mathrm{C}$ is automatically classified as solid. Both forms of precipitation can occur in between those limit values. The sums, intensity and spectrum of precipitation are reported for one-minute periods and then transmitted via a serial interface to the database (Instruction for use 2008). Due to the above, precipitation measurements conducted by means of such a precise instrument permit very thorough and accurate analysis of precipitation episodes.

The original program DisPre permits, at the start, to compile data from every month in a single file, as the data acquired by the disdrometer are saved in the complicated format provided by the manufacturer, where information from every minute is aggregated in a file containing data from one hour. The data visualisation procedures developed within the framework of the program DisPre permit the selection of any precipitation episode and its detailed analysis. The spectrum of the precipitation event selected can be analysed in three variants. The first variant relates to data processed by means of the program supplied as standard by the manufacturer of the disdrometer. The second variant analyses 11 classes of precipitation based on the classifica- tion of hydrometeors. Choosing the third variant permits the analysis of the precipitation spectrum taking into account 22 classes of particles through the compilation of 22 classes of diameters in 20 classes of velocity.

The comparative analysis of the results of measurements of diurnal sums of precipitation conducted with the methods described above was performed in several stages.

In the first stage the monthly sums of precipitation obtained with the standard Hellmann rain gauge and the laser disdrometer were compared, with the distinction between the three methods of calculation of diurnal sums of precipitation (sums generated by the original software supplied by the manufacturer of the disdrometer - method 1, sums determined on the basis of volume of particular hydrometeors - 11 particle size classes - method 2, and sums calculated on the basis of droplet diameters -22 particle size classes - method 3 ).

In the second stage a comparative analysis of diurnal sums of differences of precipitation measured with the classical method and by means of the laser disdrometer (with differentiation for the methods of their calculation) was performed. That stage included also the analysis of frequency of differences in the diurnal sums of precipitation in selected time intervals.

In the third stage the independence of strings of differences between the values of precipitation measured with the standard method and with the disdrometer (with separation for the three variants of calculation of precipitation sums) and the independence of the methods themselves were tested. For that purpose functions 
of partial and cross-autocorrelation were determined.

In the next stage a graphical method was applied, permitting the comparison of the distribution functions of the differences. Verification of the conclusions from the graphical method was performed with the use of the Kruskal-Wallis rank test, followed by the Wilcoxon test (Mann-Whitney test). The analyses were performed using the softwares Statistica 10 and Package R.

\section{RESULTS}

\section{Frequency analysis}

When comparing the monthly sums of precipitation, differences were noted between the values measured with the standard method and with the disdrometer, and between the three methods of data calculation by the disdrometer. The individual differences were small, and the reasons of their occurrence were sought directly in the methods of measurement. The use of two measuring instruments at the same time permitted cross-referencing of the results obtained.
In the second stage the frequencies of the differences were analysed. Table 1 presents the sums of the differences and the absolute differences between the standard and the three methods of data calculation by the disdrometer. On the scale of a month the sums of absolute differences between the standard and the disdrometer are large. In August significant differences were noted between the three methods of data calculation by the disdrometer.

The structure of frequency of absolute differences is presented in Figure 2. The largest amount of data falls within the range from 0 to $0.5 \mathrm{~mm}$. Among those the largest group of differences between the standard and the measurement obtained by means of the disdrometer are differences of the order of up to $0.1 \mathrm{~mm}$ (non-measurable values). Although the differences cancel one another out at the scale of a month, it is not possible to conclude which of the data calculation methods offered by the program DisPre displays the smallest differences with relation to the standard. The analysis of the issue described above was continued with the help of statistical tools.

TABLE 1. Sums of differences and absolute differences between values of measurements taken with the standard method and with the laser disdrometer for calculation method 1, calculation method 2 and calculation method 3 in July and August

\begin{tabular}{|c|c|c|c|c|}
\hline Month & Value & $\begin{array}{l}\text { Calculation metod } 1 \\
(\mathrm{~mm})\end{array}$ & $\begin{array}{c}\text { Calculation metod } 2 \\
(\mathrm{~mm})\end{array}$ & $\begin{array}{c}\text { Calculation metod } 3 \\
(\mathrm{~mm})\end{array}$ \\
\hline \multirow[b]{2}{*}{ July } & differences sums & $-4.4(4.07 \% \mathrm{mps})$ & $1.6(1.48 \% \mathrm{mps})$ & $-3.8(3.51 \% \mathrm{mps})$ \\
\hline & $\begin{array}{c}\text { absolute differences } \\
\text { sums }\end{array}$ & $14.5(13.40 \% \mathrm{mps})$ & $16.3(15.06 \% \mathrm{mps})$ & $14.9(13.77 \% \mathrm{mps})$ \\
\hline \multirow[b]{2}{*}{ August } & differences sums & $6.8(9.29 \% \mathrm{mps})$ & $7.2(9.84 \% \mathrm{mps})$ & 2.7 (3.69\% mps) \\
\hline & $\begin{array}{c}\text { absolute differences } \\
\text { sums }\end{array}$ & $9.9(13.52 \% \mathrm{mps})$ & $17.9(24.45 \% \mathrm{mps})$ & $14.3(19.54 \% \mathrm{mps})$ \\
\hline
\end{tabular}

mps - monthly precipitation sum, refers to the whole table. 


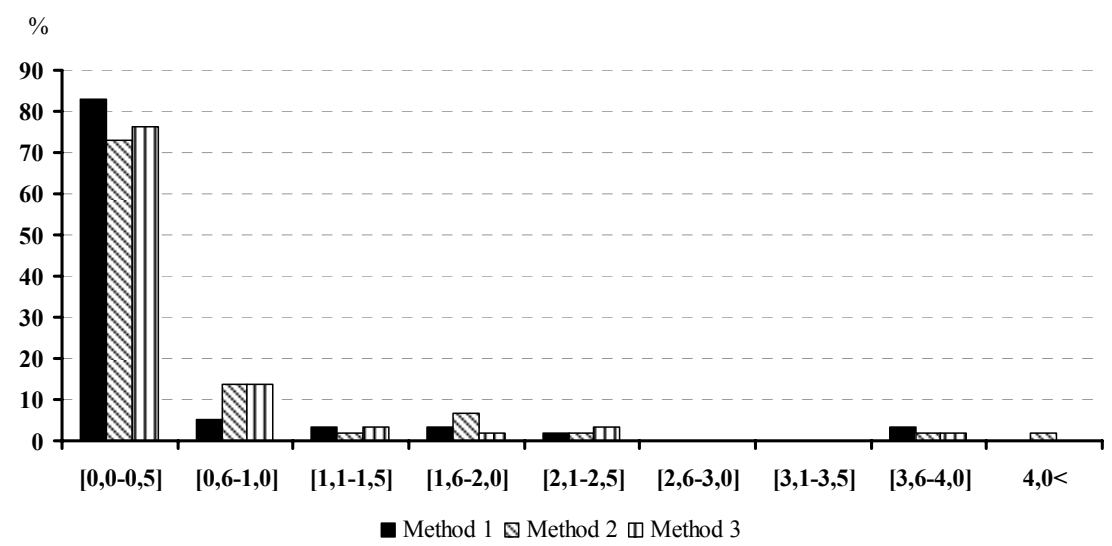

FIGURE 2. Frequency structure of absolute differences between values of diurnal sums of precipitation measured with standard Hellmann rain gauge and the disdrometer calculated by methods 1, 2 and 3

\section{Statistical analysis}

The differences between two measurement results on consecutive days form sequences of random variables $\{X(t)\}$, where $t$ is the day. An autocorrelation function was determined to verify whether $\{X(t)\}$ is a sequence of non-correlated random variables. The large concentration of data around zero (visible on the graphs of frequency of the differences) causes that we cannot verify the independence of the variables, and hence we use a substitute in the form of non-correlation.

The following assumptions were adopted: value expected is constant and variance is dependent on $t$.

Figure 3 presents the values of differences on consecutive days obtained with the use of calculation method 1. Similar

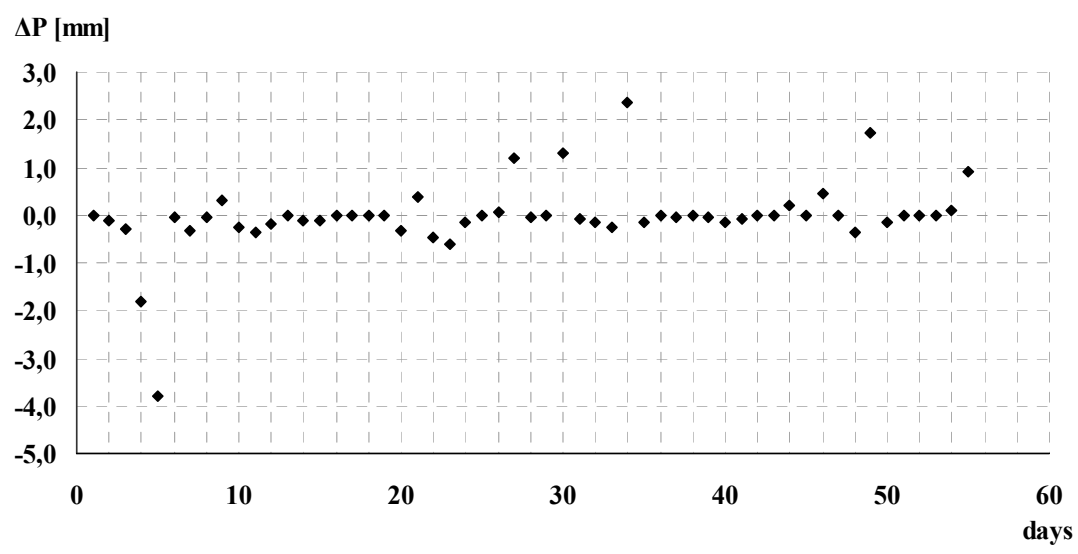

FIGURE 3. Values of differences on consecutive days during July and August 2012 between diurnal sums of precipitation measured with standard Hellmann rain gauge and disdrometer obtained with the use of calculation method 1 
graphs were obtained for the other two methods of calculation. The data are scattered around a horizontal line, and therefore the assumption concerning the expected value of the differences appears to be justified for each of the three methods of data calculation. The second assumption can be considered as fulfilled as one can easily observe that with the passage of time the points on the graph of $X(t) \mathrm{z}$ do not show any greater scatter around the mean.

The above-provided the basis for the assumption that $\operatorname{Cov}[X(t+h), X(t)]$ depends only on $h$, but does not depend on $t$. In such a case the process $X(t)$ can be called a stationary process in the broader sense. For the purpose of analysis of autocorrelation of process $X$ the following function was considered:

$$
\Gamma(h)=\frac{\operatorname{Cov}[X(1+h), X(1)]}{\operatorname{Var}[X(1)]}
$$

We do not know the gamma function, but we can estimate it by determining a sample autocorrelation function.

The hypothesis of $\mathrm{H}: \Gamma(h)=0$ was tested.

Hypothesis $\mathrm{H}$ was rejected in favour of an alternative hypothesis, when $\left|\frac{\Gamma(h)}{\sqrt{\operatorname{Var}[\hat{\Gamma}(h)]}}\right| \cdot \sqrt{N}$ is greater than a quantile of the order of e.g. 0.975 of standard normal distribution. Figure 4 presents the distribution of the obtained function of partial autocorrelation for the differences between the standard and calculation method 1. Analysis of Figure 4 suggests the conclusion that hypothesis $\mathrm{H}$ is justified.

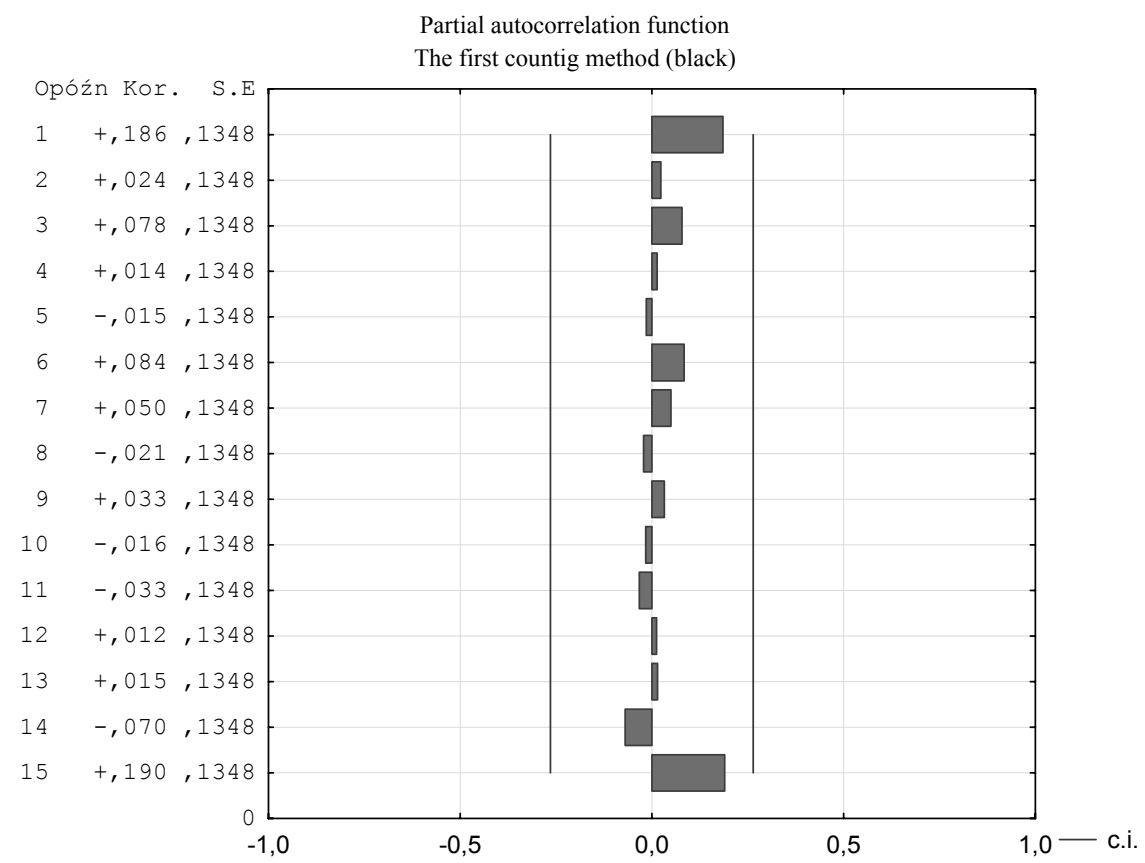

FIGURE 4. Function of partial autocorrelation for differences between the standard and calculation method 1 
The cross-correlation between the pairs of the calculation methods was also analysed. Figure 5 presents an example of the cross-correlation function for calculation method 1 and calculation method 2 .

The cross-autocorrelation functions for the other pairs of the calculation methods are similar to the example shown in Figure 5. The graphs indicate a lack of arguments against the hypothesis that the sequences of errors of the three methods are sequences of independent random variables and that there is no correlation between the errors obtained for the calculation methods under analysis.

In the search for the smallest scatter, the stochastic ordering among the absolute values of differences between the standard and the three methods of data calculation by the disdrometer was analysed. The graphical method was applied, analysing the graphs of the empirical distribution functions to discern evident trends. The empirical distribution functions of the modules of differences are presented in Figure 6.

The analysis permits the following remarks: the plot of the distribution function for calculation method 1 (marked with black on Figure 6) is situated above the other two plots (representing the differences generated by calculation method 2 and calculation method 3). The data reflecting the module of the difference between the standard measurement and the measurement obtained with calculation method 1 are lower in the stochastic order. In the first steps of developing the methodology, the method of precipitation calculation

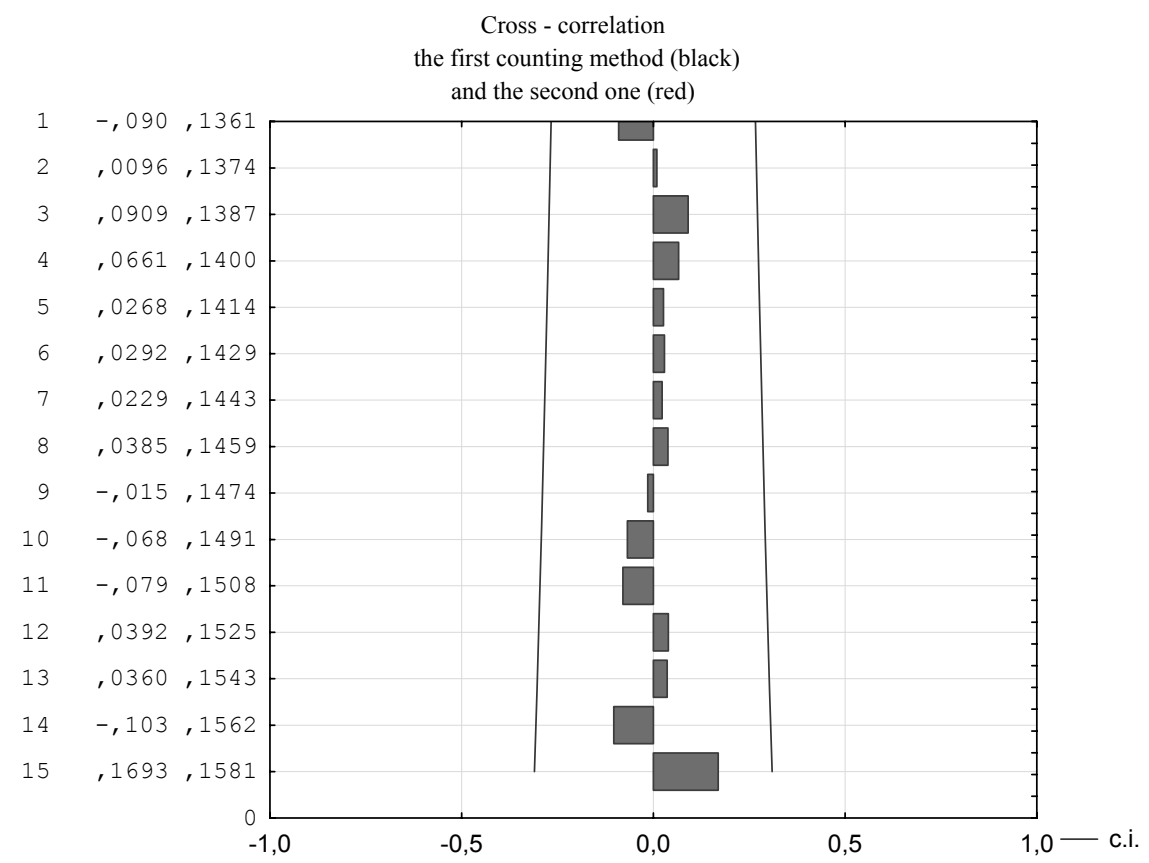

FIGURE 5. Cross-correlation function (correlation between calculation method 1 and calculation method 2) 


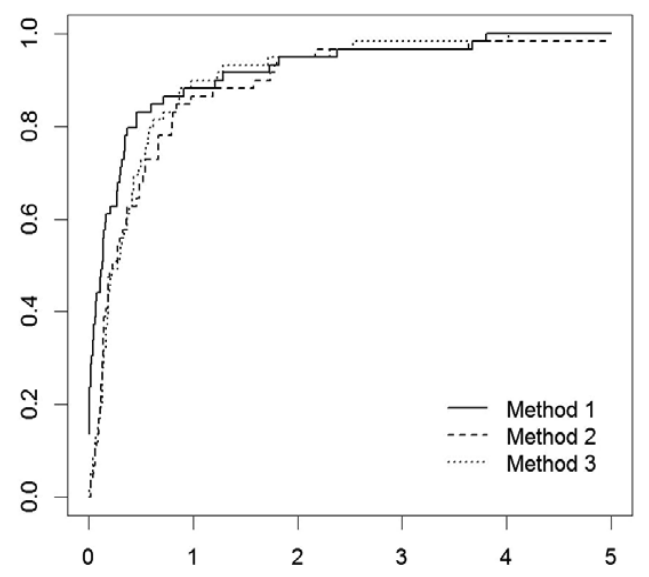

FIGURE 6. Empirical distribution functions of modules of differences

proposed by the manufacturer (marked with black) can be assumed to be the closest to the measurement performed with the Hellmann rain gauge. That conclusion was confirmed by performing the test of conformance for more than one sample (one distribution) which is used for the formulation of conclusions concerning the dominance of one distribution function over others (Kruskal-Wallis test).

The zero hypothesis was the lack of domination of any of the distribution functions, while the alternative hypothesis assumed the domination of one of the distributions (the domination does not have to be permanent, it is enough if the distribution dominates more often than the other ones):

$$
\begin{aligned}
& H: \underset{i, j}{\forall} P\left(X_{i}<X_{j}\right)=\frac{1}{2} \\
& K: \underset{i, j}{\exists} P\left(X_{i}<X_{j}\right) \neq \frac{1}{2}
\end{aligned}
$$

The adopted level of significance was 0.05 . The calculations were conducted using the program Statistica. The calculations caused the rejection of hypothesis $\mathrm{H}$, which means that among the three samples at least one dominated over one of the remaining two. To determine which of the calculation methods dominated over the other ones, the sums and the means of ranks were used. The hypothesis applied was similar to that formulated in the analysis of the plots of the distribution functions: calculation method 1 is closer to the standard (lower in the stochastic order than calculation method 2 and calculation method 3). To verify that hypothesis, the Wilcoxon test (Mann-Whitney test) was applied three times. In those tests a one-sided alternative was applied in the formulation of the hypotheses:

I.

$$
\begin{aligned}
& H: P\left(X_{1}<X_{2}\right)=\frac{1}{2} \\
& K: P\left(X_{1}<X_{2}\right)>\frac{1}{2} \\
& H: P\left(X_{1}<X_{3}\right)=\frac{1}{2}
\end{aligned}
$$

II.

$$
K: P\left(X_{1}<X_{3}\right)>\frac{1}{2}
$$

where:

$X_{i}-i$-th calculation method, $i=1,2,3$.

The results obtained caused the rejection of the zero hypothesis in favour of the alternative hypothesis. Analyses for calculation method 2 and calculation method 3 were also performed. In this case it is not possible to conclude univocally which is the lower in the sense of the stochastic order. 


\section{DISCUSSION AND CONCLUSION}

The tests provided the ultimate confirmation of the suppositions resulting from the analysis of the plots of the empirical distribution functions. The smallest scatter indicated by the graphical method for the calculation method denoted by DisPre with black colour (method 1) proved to be the closest to the measurements taken with the Hellmann rain gauge as the method of precipitation calculation during a 24-hour period.

The divergences observed between the results obtained with the two methods (Hellmann and method 1) support the results of studies with the use of disdrometers, conducted by just a few research centres on the scale of Europe and the world (e.g. Lanzinger et al. 2006, Upton and Brawn 2008, Tapiador et al. 2010). The reason for the divergences of the observed values calculated for various time steps should be certainly sought in the method of measurement itself. In the case of the disdrometer it consists in precise calculation of the precipitation sum on the basis of the volume of raindrops, even those as small as $0.125 \mathrm{~mm}$ in diameter, passing at any given moment through the light beam. A study conducted by Tapadior et al. (2010), consisting in measurements taken with the use of sixteen disdrometers distributed uniformly over a small area $\left(1 \mathrm{~km}^{2}\right)$, indicated a considerable divergence of raindrop diameter distribution (RDSD) measured simultaneously with the same method. Tapiador et al. (2012) indicate also that the Thies optical disdrometer displays a tendency to overestimate the amount of precipitation, especially in the case of squall events. Such divergences are indicated also in the studies by Lanzinger et al. (2006), De Moraes-Frasson et al. (2011), and the analyses conducted in this study also indicated such a tendency.

The practical observations of the authors, concerning the functioning of modern measurement equipment, and certainly the optical laser precipitation monitor should be classified in that category, indicate that such instruments are much more sensitive to external factors compared to the classical method. In the case of measurements conducted with the use of the disdrometer notable interference in the results was observed, caused by flying insects, which is beyond the control of the user of the equipment, by dirt accumulated on the transmitter lens and on that of light beam receiver, or by particles lifted off the ground surface by wind. As an example, during the five-year measurements it was observed that even a small spider web attached to the elements of the instrument, moved by the wind and passing through the light beam, caused the effect of "fictional precipitation". The very manner of accruing of its sum, visualised on a running basis in the program LNM View supplied as standard by the manufacturer, did not raise any concern at the first glance, and as an example it was observed that interference of this type caused an increase of $3.5 \mathrm{~mm}$ during half an hour! Another cause of generation of large errors is grass mowing, required by the Manual of the instrument to be performed on a regular basis in the area of the measurement station. Leaving the disdrometer without any protection during the mowing (e.g. by placing a protective covering on the 
receiver) results in fragments of grass, lifted up by air movement, passing permanently across the light beam and causing the visualisation of "fictional" values of precipitation sums (values as high as $140 \mathrm{~mm}$ were observed!), often on days when there was no precipitation (grass mowing was done on rainless days). In such cases the running monitoring of accruing of precipitation sum can be misleading. Therefore, to eliminate factors that can simulate precipitation, it is absolutely necessary to conduct daily checks of cleanliness of the instrument - especially in the summer period.

The above suggests the conclusion that there is no way of getting away totally from the standard method of measurement of precipitation sums. The results of precipitation measurements acquired with the use of the disdrometer, providing a wide range of interpretation possibilities, should be referenced to results of observations of that element measured with the classical methods (Hellmann rain gauge, pluviometer). In a situation where there is a lack of such verification, the chance of making serious interpretation errors increases several-fold. What is more, direct acceptance of reference values obtained by means of rain gauges of various designs, other than the accurate laser precipitation gauge used in this study, e.g. weighing gauges or tipping bucket instruments which have been the standard equipment of automatic meteorological stations for many years, can also raise numerous reservations. This is indicated by the results of studies by e.g. Kuśmierek-Tomaszewska (2009), Sevruk et al. (2009), Gołaszewski et al. (2012) or Tapiador et al. (2012).

\section{REFERENCES}

GOŁASZEWSKI D., KLENIEWSKA M. 2012: Comparison of precipitation totals measured by the automatic telepluviometer and the Hellmann rain gauge at the Warsaw Ursynów station in 2000-2010. Ann. Warsaw Univ. of Life Sciences - SGGW, Land Reclam. 44 (1), 47-54.

Instruction for use 021341/08/07 2008. Laser Precipitation Monitor 5.4110.xx.x00 V2.4x STD. Adolf Thies GmbH \& Co.KG, 64.

Instrukcja dla stacji meteorologicznych 2013 [Instruction for meteorological stations]. Instytut Meteorologii i Gospodarki Wodnej Państwowy Instytut Badawczy, Warszawa, 411 (in Polish).

KUŚMIEREK-TOMASZEWSKA R. 2009: Porównanie wyników pomiarów opadów atmosferycznych wykonywanych standardowym deszczomierzem Hellmanna i kolebkowym stacji automatycznej [Intercomparison of precipitation measurements recorded with traditional and automated tipping-bucket rain gauges]. Infrast. Ekol. Ter. Wiej. 9, 85-95 (in Polish).

LANZINGER E., THEEL M., WINDOLPH H. 2006: Rainfall amount and intensity measured by the Thies Laser Precipitation Monitor. TECO-2006, Geneva, Switzerland, 4-6 December, IOM94 (TD1354), 9.

LEHNER B., CZISCH G., VASSOLO S. 2005: The impact of global change on the hydropower potential of Europe: a model based analysis. Energy Policy 33, 839-855.

MACIAZŻEK A. 2005: Pomiary: opady atmosferyczne [Measurements - precipitation]. Gazeta Obserwatora IMGW 5, 18-23 (in Polish).

De MORAES-FRASSON R.P., Da CUNHA L.K., KRAJEWSKI W.F. 2011: Assessment of the Thies optical disdrometer performance. Atmos. Res. 101, 237-255.

Pakiet R, version: 2.11 .0 (2010-04-22).

SEVRUK B., ONDRĂAS M., CHVĬLA B. 2009: The WMO precipitation measurement intercomparisons. Atmos. Res. 92, 376-380.

SIECK L.C., STEPHEN J.B., STEINER M. 2007: Challenges in obtaining reliable measurements of point rainfall. Water Resour. Res. 43, W01420, doi:10.1029/2005WR004519.

StatSoft, Inc. 2011. Statistica (data analysis software system).Version 10. 
STRANGEWAYS I. 2010: A history of rain gauges. Weather 65 (5), 133-138.

SZULCZEWSKI W., BINIAK-PIERÓG M., ŻYROMSKI A. 2013: DisPre - program do szczegółowej analizy epizodów opadowych mierzonych $\mathrm{z}$ zastosowaniem deszczomierza laserowego [Dis-Pre - program for detailed analysis of precipitation episodes measured with laser precipitation monitor]. Materials of XLIII Seminary on Mathematics Application, Kobyla Góra, 8-11 September 2013, 85-92 (in Polish).

TAPIADOR F.J., CHECA R., DE CASTRO M. 2010: An experiment to measure the spatial variability of rain drop size distribution using sixteen laser disdrometers. Geophys. Res. Lett. 37, L16803, 6.

TAPIADOR F.J., TURK F.J., PETERSEN W., HOU A.Y., GARCIA-ORTEGA E., MACHADO L.A.T., ANGELIS C.F., SALIO P., KIDD Ch., HUFFMAN G.J., De CASTRO M. 2012: Global precipitation measurement: Methods, datasets and applications. Atmos. Res. 104-105, 70-97.

UPTON G., BRAWN D. 2008: An investigation of factors affecting the accuracy of Thies disdrometers. TECO-2008, St. Petersburg, Russian Federation, IOM 96 (TD1462), 9.

WOOD S.J., JONES D.A., MOORE R.J. 2000: Accuracy of rainfall measurement for scales of hydrological interest. Hydrol. Earth Syst. Sci. 4 (4), 531-543.

ŻYROMSKI A., BINIAK-PIERÓG M. 2014: Czy umiemy korzystać $\mathrm{w}$ nauce $\mathrm{z}$ nowoczesnych metod i urządzeń pomiarowych stosowanych w meteorologii [Can we benefit in science from the modern methods and measurement devices applied in meteorology]. Materials of the seminary on "Problems in meteorological measurements", 24 June 2014, Wrocław, 23-27 (in Polish).

Streszczenie: Ocena metod analizy porównawczej sum opadów atmosferycznych mierzonych metoda klasycznq i bezstykowym deszczomierzem laserowym. W pracy przeprowadzono analize porównawczą wyników pomiarów dobowych sum opadów atmosferycznych prowadzonych metodą standardową z zastosowaniem klasycznego deszczomierz Hellmanna oraz optycznego deszczomierza laserowego firmy Thies Clima - disdrometru. W tym celu wykorzystano dobowe wyniki pomiarów opadów atmosferycznych prowadzonych od 1 lipca do 31 sierpnia 2012 roku na terenie Wydziałowego Obserwatorium Agro i Hydrometeorologii należącego do Uniwersytetu Przyrodniczego we Wrocławiu. Informacje o opadach pomierzonych deszczomierzem laserowym i przetworzone za pomocą autorskiego oprogramowania DisPre pozwoliły na rozróżnienie trzech sposobów zliczania sum dobowych opadów (sumy generowane przez oryginalne oprogramowanie dostarczone przez producenta disdrometru, sumy wyznaczone na podstawie objętości poszczególnych hydrometeorów - 11 klas cząsteczek, oraz sumy obliczone na podstawie średnic kropel - 22 klasy cząsteczek). Przeprowadzone analizy wskazują, że sumy generowane przez oryginalne oprogramowanie producenta są najbardziej zbliżone do wartości pomierzonych klasycznym deszczomierzem. Rozbieżności w pozyskanych wartościach upatrywać należy w samej metodzie prowadzenia pomiaru. $Z$ uwagi na bardzo dużą wrażliwość disdrometru na czynniki zewnętrzne należy bezwzględnie dokonywać kontroli czynności tego urządzenia, zwłaszcza w okresie letnim.

Stowa kluczowe: sumy opadów, deszczomierz Hellmanna, deszczomierz laserowy, analiza porównawcza

\section{MS. received November 2015}

\section{Authors' address:}

Małgorzata Biniak-Pieróg

Instytut Kształtowania i Ochrony Środowiska

Uniwersytet Przyrodniczy we Wrocławiu

Plac Grunwaldzki 24, 50-363 Wrocław

Poland

e-mail: malgorzata.biniak-pierog@up.wroc.pl 